\title{
The face of myasthenia gravis
}

Annabel M. Ruiter, MD, Willemijn C. Naber, MD, Jan J.G.M. Verschuuren, MD, PhD, and Martijn R. Tannemaat, MD, PhD

Neurology ${ }^{\circledR}$ 2020;95:89-90. doi:10.1212/WNL.0000000000009782

\section{Correspondence}

Dr. Ruiter

a.m.ruiter@lumc.nl

Figure The face of myasthenia gravis (MG)

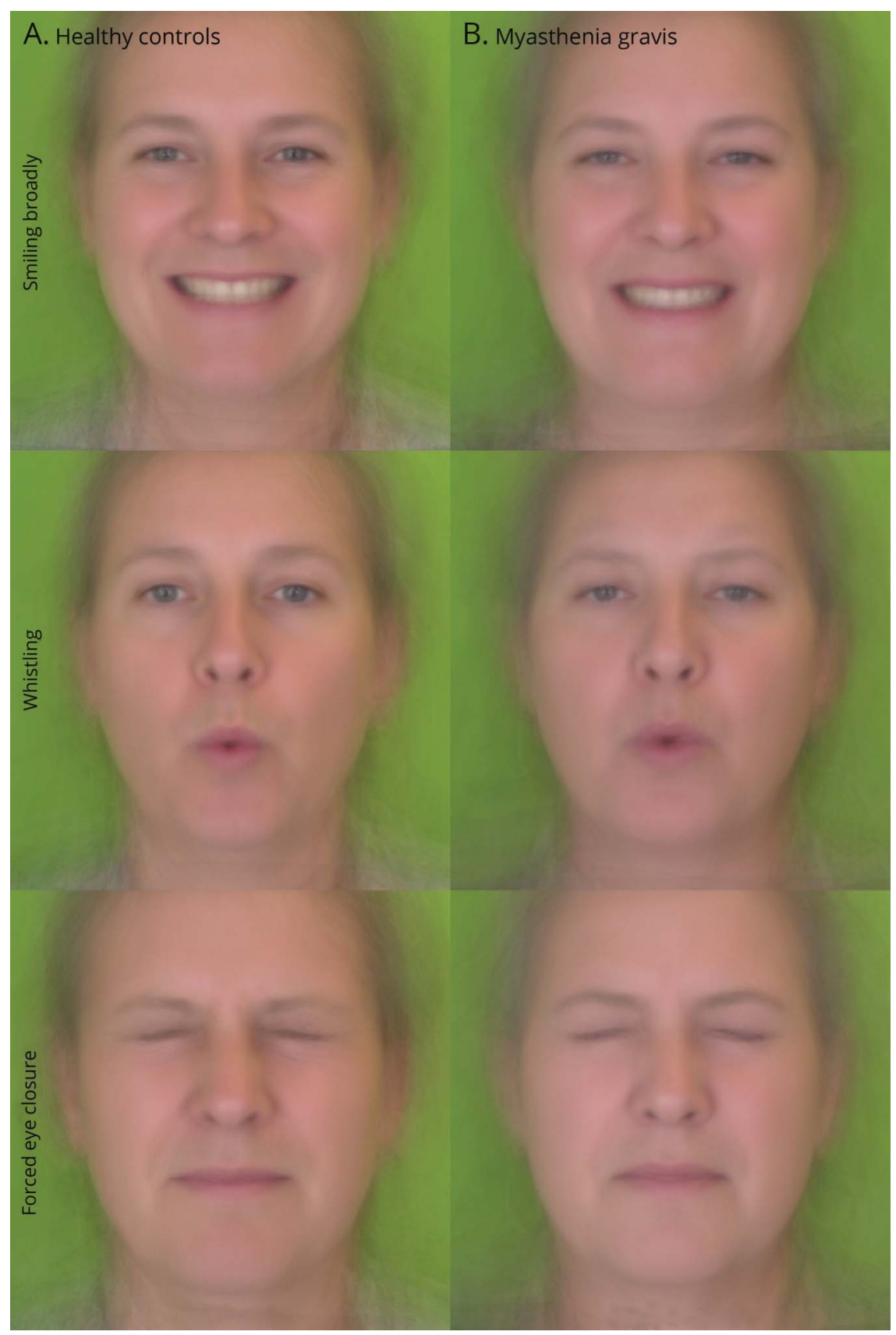

(A) Healthy controls $(n=38), 44.7 \%$ male, mean (SD) age $48.6( \pm 16.3)$ years. (B) Patients with MG $(n=52), 36.5 \%$ male, mean (SD) age $54.8( \pm 18.7)$ years. Mean (SD) quantitative MG score for disease severity was $9.2( \pm 4.8)$.

From the Department of Neurology, Leiden University Medical Center, the Netherlands.

Go to Neurology.org/N for full disclosures. Funding information and disclosures deemed relevant by the authors, if any, are provided at the end of the article. 
Myasthenia gravis (MG) is characterized by fluctuating weakness and fatigability of skeletal muscles. In most patients, extraocular and bulbar muscles are affected first, leading to diplopia, ptosis, and weakness of facial muscles. ${ }^{1}$ We recorded the faces of 38 healthy controls and 52 patients with MG while performing a standardized set of facial expressions. These images were averaged using Python version 3.8.0. This resulted in highly similar faces with no recognizable individual features. The only discernible differences are typical clinical hallmarks of the disease: ptosis and generalized facial weakness around the eyes and mouth resulting in less vivid facial expression (figure).

\section{Study funding}

No targeted funding reported.

\section{Disclosure}

The authors report no disclosures relevant to the manuscript. Go to Neurology.org/N for full disclosures.
Appendix Authors

\begin{tabular}{lll}
\hline Name & Location & Contribution \\
\hline $\begin{array}{l}\text { Annabel M. } \\
\text { Ruiter, MD }\end{array}$ & $\begin{array}{l}\text { Department of Neurology, } \\
\text { Leiden University Medical } \\
\text { Center, the Netherlands }\end{array}$ & Wrote the manuscript \\
\hline $\begin{array}{l}\text { Willemijn C. } \\
\text { Naber, MD }\end{array}$ & $\begin{array}{l}\text { Department of Neurology, } \\
\text { Leiden University Medical } \\
\text { Center, the Netherlands }\end{array}$ & $\begin{array}{l}\text { Gathered photographs } \\
\text { of each individual } \\
\text { participant used for } \\
\text { averaging }\end{array}$ \\
\hline $\begin{array}{l}\text { Jan J.G.M. } \\
\text { Verschuuren, } \\
\text { MD, PhD }\end{array}$ & $\begin{array}{l}\text { Department of Neurology, } \\
\text { Leiden University Medical }\end{array}$ & $\begin{array}{l}\text { Reviewed and } \\
\text { corrected the } \\
\text { manuscript }\end{array}$ \\
$\begin{array}{l}\text { Martijn R. } \\
\text { Tannemaat, } \\
\text { MD, PhD }\end{array}$ & $\begin{array}{l}\text { Department of Neurology, } \\
\text { Leiden University Medical }\end{array}$ & $\begin{array}{l}\text { Reviewed and } \\
\text { corrected the } \\
\text { Center, the Netherlands }\end{array}$ \\
\hline
\end{tabular}

\section{Reference}

1. Gilhus NE, Tzartos S, Evoli A, Palace J, Burns TM, Verschuuren J. Myasthenia gravis. Nat Rev Dis Primers 2019;5:30.

\section{AAN Online Learning}

Browse a variety of online CME, self-assessment, and other learning activities to suit your wide-ranging interests and learning styles. Visit AAN.com/Learn.

\section{Subspecialty Alerts by E-mail!}

Customize your online journal experience by signing up for e-mail alerts related to your subspecialty or area of interest. Access this free service by clicking on the "My Alerts" link on the home page. An extensive list of subspecialties, methods, and study design choices will be available for you to choose from-allowing you priority alerts to cutting-edge research in your field!

\section{Did You Know...}

... you can browse by subspecialty topics on Neurology.org?

Go to: Neurology.org and click on "Topics" in the top navigation bar. 


\section{Neurology}

The face of myasthenia gravis

Annabel M. Ruiter, Willemijn C. Naber, Jan J.G.M. Verschuuren, et al.

Neurology 2020;95;89-90 Published Online before print June 10, 2020

DOI 10.1212/WNL.0000000000009782

This information is current as of June 10, 2020

Updated Information \& Services

References

Subspecialty Collections

Permissions \& Licensing

Reprints including high resolution figures, can be found at:

http://n.neurology.org/content/95/2/89.full

This article cites 1 articles, 0 of which you can access for free at: http://n.neurology.org/content/95/2/89.full\#ref-list-1

This article, along with others on similar topics, appears in the following collection(s):

Clinical neurology examination

http://n.neurology.org/cgi/collection/clinical_neurology_examination Myasthenia

http://n.neurology.org/cgi/collection/myasthenia

Information about reproducing this article in parts (figures,tables) or in its entirety can be found online at:

http://www.neurology.org/about/about_the_journal\#permissions

Information about ordering reprints can be found online:

http://n.neurology.org/subscribers/advertise

Neurology ${ }^{\circledR}$ is the official journal of the American Academy of Neurology. Published continuously since 1951, it is now a weekly with 48 issues per year. Copyright @ 2020 American Academy of Neurology. All rights reserved. Print ISSN: 0028-3878. Online ISSN: 1526-632X.

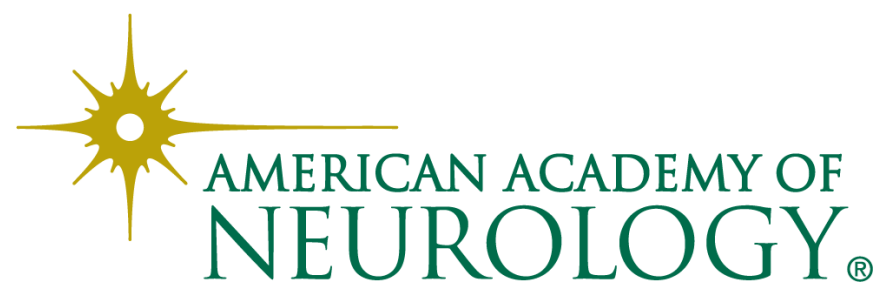

